\title{
VARIATION OF BIOMASS IN GRASSES GROWING IN WATER HABITAT BETWEEN INLAND SWAMP AND LAND
}

\author{
Virgina Maria Louisa ${ }^{1}$, Krisdianto $^{2}$, Mahrita $^{3}$ \\ ${ }^{1}$ Graduate Program of Natural Resources and Environmental Management \\ Email: louisjiang.ll@gmail.com \\ 2 Department of Biology, Faculty of Mathematics and Natural Sciences \\ ${ }^{3}$ Department of Agronomy, Faculty of Agriculture \\ Lambung Mangkurat University, Banjarbaru, South Kalimantan
}

\begin{abstract}
Grasses (family Poaceae), which belong to the weeds growing in water habitat between inland swamp and land, have the ability to survive the inland swamp environment that is inundated and poor in nutrients due to acidic soil. Lowland between inland swamp and land experiences waterlogging condition that changes over time from a puddle of water, which is very high in the rainy season, to ebb, becoming dry especially during the dry season. The objective of this study was to find out the variation of biomass in some grasses growing in water habitat between inland swamp and land. The study was conducted from April to July 2009 in Banjar Regency, South Kalimantan, at the villages of Tungkaran, Sungai Rangas, Penggalaman, and Sungai Tabuk. The analysis of samples was carried out at the Basic Laboratory of Faculty of Mathematics and Natural Siences, Lambung Mangkurat University Banjarbaru. There were seven stations, which were determined purposively, with three plot replications; the smallest plot was $20 \times 20 \mathrm{~cm}$. Three types of grass samples were taken and measured for individual height, wet weight, dry weight, moisture content and ash content. Measurements of the environmental parameters included the $\mathrm{pH}$ of soil and water, and the analysis of total N, P, and $\mathrm{K}$. The average dry weight biomass of Hymenachne amplexicaulis, Brachiaria plantaginea, and Brachiaria mutica ranged from $1,135.18$ to $2,556.80 \mathrm{gm}^{-2}, 1,854.88$ to $2,480.63 \mathrm{gm}^{-2}$, and $1,353.98$ to $3,204.9 \mathrm{gm}^{-2}$, respectively. These results indicate that the grasses growing closer to land, namely Brachiaria plantaginea and Brachiaria mutica, have higher biomass than the one growing a bit far from the land, namely Hymenachne amplexicaulis.
\end{abstract}

Keywords: biomass, grass, inland swamp, Poaceae

\section{INTRODUCTION}

Plant biomass is the mass of the living parts of plants (Sitompul \& Guritno, 1995) covering the crowns of trees, understory vegetation or weeds and annual plants (Hairiah \& Rahayu, 2007) that is expressed in the weight of organic materials per area unit or volume (Soegianto, 1994). Miller argues that the plant biomass is formed from the substance produced in the plant tissue with raw materials from the environment and the energy source from the sun (Khiatuddin, 2003). According to Abercrombie et al. (1993), biomass refers to dry weight or ash free dry weight.

One of the areas producing biomass is wetland. Wetlands include swamps, lakes, rivers, estuaries, and beaches with a depth of less than six meters at low tide time, natural or artificial, permanent or temporary puddles, still or flowing, sweet, salty or brackish. (Notohadiprawiro, 1996).

In Indonesia, there are extensive wetlands, around 33.5 million ha, consisting of 20.2 million hectares of tidal swamps and 13.3 million ha of inland swamps (Nugroho, 1993). The spread of inland swamps is between the lands and water systems, namely between dry lands and rivers or lakes, or between lands and seas. Inland swamps are in the curves, depressions or the lowest parts of the lowlands to highlands. The specificity of inland swamps is that the flood often occurs with the water depth fluctuations hard to be predicted in the rainy season, and vice versa the drought occurs in the dry season (Salwati et al, 2008). The always-inundated condition in inland swamps make the rate of organic matter accumulation greater than the recycle, resulting in the accumulation of thick organic matter, and cause the increased soil acidity (Noor, 2007).

Although the swamp environment is not suitable for most landplants, wetland is one of the productive ecosystems on the 
earth's surface to produce biomass. The productivity can be achieved because swamps permanently receive the overflow of nutrients (contained in the water pollutants) and the water coming from the land around the swamps that supports the growth of plants (Khiatuddin, 2003). Plants that live in inland swamps are very diverse ranging from the types of trees, shrubs, bushes, and grasses. The grass included in the group of weeds is generally a source of organic matter and nutrients, as well as compost matterials (Noor, 2007).

The results of the identification of weeds by Haryatun (2008) at the inland swamps in the sub-districts of Nagara, Labuan Amas Selatan, and Danau Panggang indicate that there were 25 weed species consisting of 17 species of broadleaf groups, 5 species of grass groups, and 3 species of teki groups. Of the 25 species, there were 14 weed species that were dominant, namely 10 species of broadleaf weeds, 3 species of grass weeds, and one species of teki weeds. The three dominant grass weed species were Kumpai Babulu (Paspalidum punctatum), Suket Timunan (Leptochloa chinensis) and Utulan (Sacciolepis interupta).

The varied environmental conditions from one place to another and the crop need for specific environmental conditions, which lead to the diversity of the thriving plant species, can occur in different places (Sitompul \& Guritno, 1995). Herbaceous plants have the ability to face the environmental conditions of swamps, which is the ability to adapt to puddle, acidity, and lack of nutrients (Noor, 2007). The edge territory between inland swamp and land experiences the changing waterlogging conditions from a puddle of water that is very high in the rainy season to the ebb that becomes dry particularly during the dry season. This condition affects the biomass of various types of grasses in addition to the dependence on the diversity and density of existing plants, as well as the way it is managed (Hairiah and Rahayu, 2007).

The objective of this study was to find out the variation of biomass in some grasses growing in the water habitat between inland swamp and land.

\section{MATERIALS AND METHODS}

This study was conducted for four months from April to July 2009 in Banjar Regency, South Kalimantan Province, in the villages of Tungkaran, Keramat Baru, Sungai Rangas, Penggalaman, and Sungai Tabuk. The analysises of grasses and soil samples were carried out at the Basic Laboratory of Mathematics and Natural Science Faculty, Lambung Mangkurat University Banjarbaru.

Sampling stations were determined purposively. The consideration in determining the sampling stations was where samples can represent any type of grass. The area of inland swamp taken was dry land to shallow inland swamp and mid inland swamp. Based on the distance and the existence of grass species, seven sampling stations were determined. Three spots for plot placements as replications were made in each station. The minimum size of the smallest plot was $20 \times 20 \mathrm{~cm}$. The number of grass plants in the smallest plot was measured and converted into an area of $1 \times 1 \mathrm{~m}$.

The grass height was measured with the meter, from the boundary between the grass root and stem at ground level to the tip of the leaves straightened up which were parallel with the stem (Sitompul and Guritno, 1995).

Each stem of grass was weighed to obtain the wet weight. Ten grasses were cut and then wrapped in paper and put in the oven at $80^{\circ} \mathrm{C}$ for 48 hours. The grasses that had been put into the oven were weighed to obtain the dry weight. The drying in the oven and grass sample weighing were carried out several times until a constant dry weight was obtained. The percentage of water content was obtained from the reduction of the wet weight by the dry weight of the samples.

Grass biomass was calculated in the gram units of wet weight and dry weight per square meter $\left(\mathrm{m}^{2}\right)$.

$$
\text { Biomass }=\frac{W(g) x \sum \text { Plant }\left(m^{2}\right)}{\text { Width of area }\left(m^{2}\right)}
$$

Note: $\mathrm{W}=$ wet weight or dry weight per plant

The soil sampling for each station was performed at three different spots using a ground drill. Soil samples were wind-dried for 48 hours and pulverized. The analysis of soil samples was performed for the soil $\mathrm{pH}$, total $\mathrm{N}$, total $\mathrm{P}$, and total $\mathrm{K}$.

Water sampling was carried out using clean plastic bottles and rinsed beforehand with water at each station. The bottles were filled to the brim and transported to the laboratory without shaken so as not to cause 
a change in condition. Prior to the analysis, the bottles were shaken so that the solution became homogeneous (Alaerts, 2000). The analysis of water sample was performed for the water $\mathrm{pH}$.

\section{RESULTS AND DISCUSSION}

The dominant grass species growing at all stations were Hymenachne amplexicaulis, Brachiaria plantaginea, and Brachiaria mutica. The dominance of the three grasses was thought to occur because they had better ability to adapt to water habitat between inland swamp and land compared to any other grasses.

This adaptability was showed from the results of the environmental parameter measurements indicating the condition of total $\mathrm{N}$ ranging from very low to moderate, and the total $\mathrm{P}$ and $\mathrm{K}$ which were very low. In addition, it is also supported by the soil $\mathrm{pH}$ that was acidic and the water $\mathrm{pH}$ that was slightly acidic. The optimum $\mathrm{pH}$ for the soil nutrient availability is about 7.0 since at this $\mathrm{pH}$ all macro elements are available to the maximum while the micro-nutrients are not maximal. Acidic soil affects the availability of nutrients in the soil (Hanafi, 2005).

One of the growth indicators easily observed in the group of grasses (Poaceae) is the size of the plants that can be considered as higher plants (Sitompul and Guritno, 1995). Based on the results, the highest average height of the three grass species (Table 1) was at stations 7 and 4 and the lowest at stations 2, 5 and 6. This is thought to occur because of the availability of nutrients to support for better growth. The availability of nutrients in the soil have a pattern of nutrient content whose composition varies based on the condition of $\mathrm{pH}$. For example, the pattern of low - very low in total $\mathrm{N}$ and $\mathrm{P}-\mathrm{K}$ at station 7.

Table 1 Average plant height of 3 grass species

\begin{tabular}{cccc}
\hline \multirow{2}{*}{ Station } & \multicolumn{3}{c}{ Average height of plant $(\mathrm{cm})$} \\
\cline { 2 - 4 } & $\begin{array}{c}\text { Hymenachne } \\
\text { amplexicaulis }\end{array}$ & Brachiaria plantaginea & Brachiaria mutica \\
\hline 1 & 56.01 & 58.67 & 88.33 \\
2 & 57.90 & 50.37 & 71.83 \\
3 & 49.03 & 70.27 & 68.47 \\
4 & 60.40 & 73.87 & 89.23 \\
5 & 41.73 & 65.30 & 67.10 \\
6 & 55.03 & 64.20 & 58.17 \\
7 & 66.60 & 74.53 & 81.27 \\
\hline
\end{tabular}

Based on the frequency distribution, it is found out that it was hard to find the height of any of the three species that was more than $100 \mathrm{~cm}$. The height of Hymenachne amplexicaulis was $50-100 \mathrm{~cm}$ (Prosea, 2000), while Brachiaria plantaginea had a high range of individuals $40-100 \mathrm{~cm}$ (Clayton et. al., 2008b) and Brachiaria mutica had the height range of individuals $25-125 \mathrm{~cm}$ (Clayton et. al., 2008a ).

Among the grasses of the three species, only a few was higher than $100 \mathrm{~cm}$. This is due to the $\mathrm{pH}$ of the soil and water that affect the availability of nutrients in the soil and its solubility in water, affecting the growth of grass. Based on the results of measurement, it was found out that the soil $\mathrm{pH}$ at each station was acidic and the $\mathrm{pH}$ of the water at each station was slightly acidic. According to Noor (2007), inland swamps have the water quality classified as good to moderate with a $\mathrm{pH}$ ranging from $5-7$. It is influenced by the season and the type of soil.

The growth in the population can be found out by counting the number of plants in an area (Table 2). The highest average number of grass species Hymenachne amplexicaulis was at station 4 and the lowest at stations 6 and 7. Brachiaria plantaginea had the highest average height at Station 7 and the lowest at Station 1. Brachiaria mutica had a number of plants with the highest average at 7 station and the lowest at station 4. The number of plants of each grass species had a considerable margin. It was influenced by the size of the plant body (thin or fat). The larger the size of the plant body, the smaller the number of individuals per unit area. 
Virgina Maria Louisa, Krisdianto, Mahrita : Variation Of Biomass In Grasses Growing In Water

Table 2 Average number of 3 grass species on an area of $1 \mathrm{~m}^{2}$ at 7 stations

\begin{tabular}{cccc}
\hline \multirow{3}{*}{ Station } & \multicolumn{3}{c}{ Average number of plants (stems) } \\
\cline { 2 - 4 } & $\begin{array}{c}\text { Hymenachne } \\
\text { amplexicaulis }\end{array}$ & $\begin{array}{c}\text { Brachiaria plantaginea } \\
\text { Brachiaria mutica }\end{array}$ \\
\hline 1 & 617 & 692 & 700 \\
2 & 692 & 733 & 692 \\
3 & 683 & 800 & 525 \\
4 & 783 & 775 & 475 \\
5 & 575 & 783 & 517 \\
6 & 558 & 783 & 742 \\
7 & 558 & 825 & 767 \\
\hline
\end{tabular}

The highest average wet weight of Hymenachne amplexicaulis, Brachiaria plantaginea, and Brachiaria mutica (Table 3) was at station 7,1 , and 6 , respectively while the lowest average wet weight of Hymenachne amplexicaulis, Brachiaria plantaginea, and Brachiaria mutica was at station 5,2 , and 1 , respectively. The highest height does not always give the highest wet weight of plant. It occurs because the varied sizes of the plant body, thin or thick.

Table 3 Average wet weight of 3 grass species at 7 stations

\begin{tabular}{cccc}
\hline \multirow{3}{*}{ Station } & \multicolumn{3}{c}{ Average wet weight per plant $(\mathrm{g})$} \\
\cline { 2 - 4 } & $\begin{array}{c}\text { Hymenachne } \\
\text { amplexicaulis }\end{array}$ & Brachiaria plantaginea & Brachiaria mutica \\
\hline 1 & 15.88 & 12.79 & 12.73 \\
2 & 17.34 & 8.84 & 14.16 \\
3 & 10.43 & 10.84 & 14.06 \\
4 & 14.31 & 10.68 & 13.96 \\
5 & 9.43 & 10.56 & 14.20 \\
6 & 22.48 & 9.95 & 22.77 \\
7 & 28.24 & 10.96 & 21.97 \\
\hline
\end{tabular}

The highest average dry weight of Hymenachne amplexicaulis and Brachiaria mutica (Table 4) was at station 6 while Brachiaria plantaginea at Station 3 , compared to other stations. The lowest average dry weight of Hymenachne amplexicaulis, Brachiaria plantaginea, and Brachiaria mutica was at station 4, 2 and 5, respectively.

Table 4 Average dry weight of 3 grass species at 7 stations

\begin{tabular}{cccc}
\hline \multirow{2}{*}{ Station } & \multicolumn{3}{c}{ Average dry weight per plant $(\mathrm{g})$} \\
\cline { 2 - 4 } & $\begin{array}{c}\text { Hymenachne } \\
\text { amplexicaulis }\end{array}$ & $\begin{array}{c}\text { Brachiaria plantaginea } \\
\text { Brachiaria mutica }\end{array}$ \\
\hline 1 & 2.07 & 3.09 & 4.20 \\
2 & 1.76 & 2.59 & 3.69 \\
3 & 1.67 & 3.12 & 2.78 \\
4 & 1.51 & 3.04 & 2.84 \\
5 & 2.43 & 3.09 & 2.71 \\
6 & 4.61 & 3.07 & 4.25 \\
7 & 4.03 & 3.01 & 4.19 \\
\hline
\end{tabular}

The amount of biomass is influenced by the number of plants and wet weight (Figure 1). The highest biomass (average wet weight) of Hymenachne amplexicaulis was at station 7 and the lowest at station 5 .
The wet weight biomass of Hymenachne amplexicaulis at station 7 was the highest because it had the lowest number of plants with the highest wet weight while the wet weight biomass at station 5 was the lowest 
because it had a number of plants that were not high but had the very low wet weight, compared with the wet weight at other stations.

The highest average wet weight biomass of Brachiaria plantaginea was at station 7 because it had the highest number of plants with not too high wet weight while the lowest was at station 2 because it had low wet weight but the number of plants was not high compared with the lowest number of individuals at station 1 .

The highest biomass of the average wet weight of Brachiaria mutica was at station 7 because it had the highest number of plants with not too high wet weight, and the lowest was at station 4 because it had the lowest number of plants but the wet weight was not lower than the lowest wet weight at Station 1.

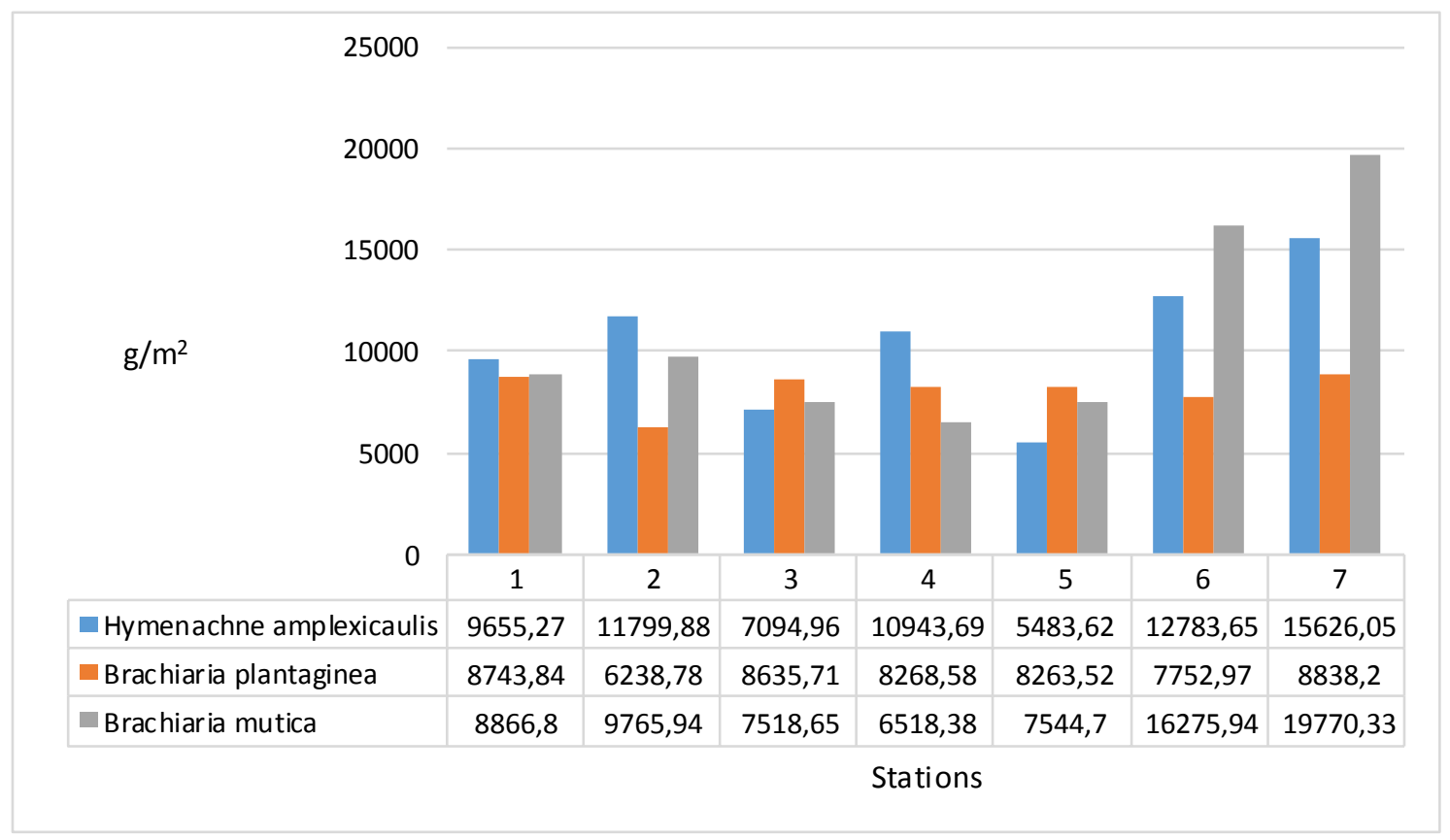

Figure 1 Average biomass of wet weight of three grass species at 7 stations.

The highest biomass of the average dry weight of Hymenachne amplexicaulis was at station 6 because the number of plants was not high, with the highest dry weight. The lowest biomass of the average dry weight of Hymenachne amplexicaulis was at station 3 because the number of plants was not low and the dry weight was not lower than the lowest dry weight at station 4.

The highest biomass of the average dry weight of Brachiaria plantaginea was at station 3 because the number of plants was not high with the highest dry weight while the lowest was at station 2 because the number of plants was not low with the lowest dry weight.

The highest biomass of the average dry weight of Brachiaria mutica was at station 7 because it had the highest number of plants with not high dry weight while the lowest was at station 4 because it had the lowest number of plants with the dry weight that was not low compared with the lowest dry weight at station 5 . 


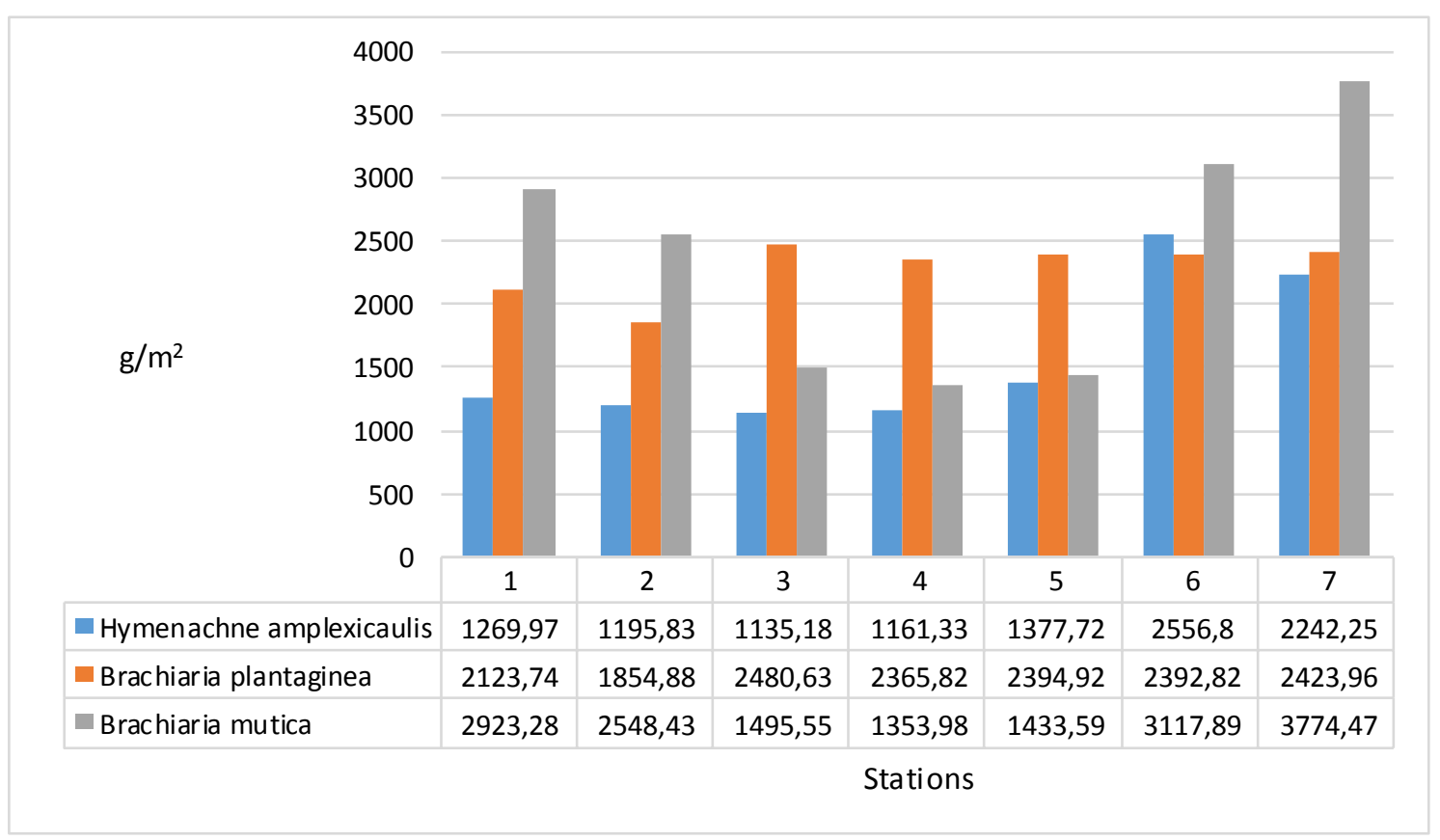

Figure 2 Average biomass of dry weight of 3 grass species at 7 stations

When compared with Imperata cylindrica on land, producing 2-11 tons ha-1 (Prosea, 2000), it was found out that the amount of dry weight biomass of the three grass species was high. The amount of Hymenachne amplexicaulis biomass was 510 tons ha- ${ }^{-1}$ (Prosea, 2000) whereas the number of plants obtained ranged from 11-25 tons ha $^{-1}$, Brachiaria plantaginea from 18-24 tons ha $^{-1}$, and Brachiaria mutica from 5-12 ha $^{-1}$ with the number obtained ranged from 13-32 tons ha-1 (Prosea, 2000).

\section{CONCLUSION}

It can be concluded that the dry weight biomass per square meter of grasses growing closer to the land, namely Brachiaria plantaginea and Brachiaria mutica, was higher in amount than that of grass growing a bit far from the land like Hymenachne amplexicaulis.

\section{REFERENCES}

Abercombie, M., Hickman, M., Jhonson, M.L. and Thain, M. (1993). Complete Dictionary of Biology. $8^{\text {th }}$ edition. Erlangga. Jakarta.

Alaerts, G. and Santika, S.S. (2000). Methods for Water Research. Usaha Nasional. Surabaya.
Hairiah, K. and Rahayu, S. (2007). A Practical Guide: Measuring Carbon Stored in A Wide Variety of Land Use. World Argoforestry Centre (ICRAF). Bogor.

Haryatun (2008). Identification Techniques of Dominant Weed Species and Availability Status of Nitrogen, Phosphor, and Potassium in Several weed species in Inland Swamps. Agricultural Technique Bulletin.13:19-22.

http://www.pustakadeptan.go.id/publikasi/bt131086.pdf

Khiatuddin, M. (2003). Preserving Water Resources with Technology of Artificial Swamp. Gadjah Mada University Press. Yogyakarta.

Nugroho, K., Alkusuma, Paidi, Wahdini, W., Abdurachman, Suhardjo, $H$. and Widjaja-Adhi, I P.G. (1993). A Map of Potential Areas for Agricultural Development of Tidal Wetlands, Swamps dan Coasts. Research Project of Land Resources. Soil and Agro-climate Research Center, Agricultural Research Agency.

Noor, M. (2007). Inland Swamps: Ecology, Utilization, and Development. Rajawali Press. Jakarta.

Notohadiprawiro, T. (1996). Recognizing the essence of Land Swamp as a Basis 
Virgina Maria Louisa, Krisdianto, Mahrita : Variation Of Biomass In Grasses Growing In Water

for Food Crop Development. Repro: Soil Science. Gadjah Mada University (2006). http://soil.faperta.ugm.ac.id/ti/1991/ 1996\%20meng.pdf

Prosea (Plant Resources of South-East Asia). (2000). Plant Resources of Southeast Asia 4: Feed. $1^{\text {st }}$ edition. Balai Pustaka. Jakarta.

Salwati, Mulyatri, and Prayudi, B. (2008). Water Planning Strategy in Inland Swamps of Jambi Province.. http://balittra.litbang.deptan.go.id:80 /prosiding06/Document15.pdf

Sitompul, S.M. and Guritno, B. (1995). Analysis of Plant Growth. Gadjah Mada University Press, Yogyakarta.

Widjaja-Adhi, I.P.G., Suriadikarta, D.A., Sutriadi, M.T., Subiksa, I.G.M. and Suastika, I.W. (2000). Management, Utilization and
Development of Wetlands. Page 127-164. 